\title{
THE DEPENDENCY OF THE PRICES OF FARM ESTATES ON ARABLE LAND AND FOREST LAND AREAS IN FINLAND IN THE YEARS 1961, 1962 AND 1966.
}

\author{
Arvi Leponiemi \\ Research Bureau of the Kyösti Haataja Foundation, Helsinki
}

Received September 13, 1968

It is the aim of this research to expose the determinants of the sales prices of farm estates in Finland in the years 1961, 1962 and 1966, using empirical methods. It is particularly endeavored to clarify the dependency of the sales price of farm estates on the agricultural land and forest land areas by means of regression analysis. Of the many uses of land, only its agricultural and forestry-economic use are examined. However, the practising of other than full-time livelihood, for instance side-line jobs, is not contained in this research. Owing to the defectiveness of statistical material available it has not been possible to observe explicitly the value of the buildings on farms nor the quality of the land, and these deficiencies will certainly influence the results. For testing the hypothesis, used as a starting point of the research, there are used cross-section samples of sales of farm estates during the years 1961, 1962 and 1966 (LePonIEMI and LAMmi), especially collected for the purpose.

From among several alternatives, such as interviewing the sellers, consulting the taxation statistics and collecting the data from the notaries publics through the census offices, the last-mentioned was chosen for several reasons. Since the notaries publics usually record the land register number of the real estate sold, the selling price, the seller and the buyer, but not, as a rule, the area of the farm, additional information had to be acquired from the provincial surveying offices.

To enable as accurate recording as possible of the normal selling price, the following were eliminated: sales of land in units less than 2 hectares; sales between relatives; land sold by the heirs and sales of the deceased persons' estates; sales where the State or a municipality appeared as the seller or the buyer; sales where the selling price included pensions or other privileges; donations and mutual exchange of real estate; sales made by or to firms. Also, so-called sales among friends were excluded. And a number of sales had to be disregarded on account of ambiguous land register entries. The final sample consisted of 2,555 sales accounting for no more than 6.1 per cent of the original sample in 1961,1457 sales (3.7 per cent) in 1962 and of 1290 sales (2.3 per cent) in 1966. 


\section{Building up the hypothesis}

From the viewpoint of micro-economics the sales price of a farm estate reflects the estimates of both the buyer and the seller, which estimates contain, in addition to the return value of the land, also components, such as the proximity of schools and service centers as well as other environmental factors. Although the sales price of a farm estate most often depends very much on the area of the estate, it can be assumed that on the average, the buyer considers the estate as an:

1) investment object,

2) a working place, and

3) a residence. (Nõu 1955).

However, in this research it is only possible to observe the investment component of the sales price.

On observing the behaviour of the buyer of a farm estate, we now limit ourselves to a case in which other factors of production than the agricultural and forest land are not considered, the rate of interest is constant and the unit prices of the products of the arable land and the forest are also constant. Thus, for the sake of simplicity, it is assumed that the farm estate continually produces a return of equal size, $\mathrm{y}_{\mathrm{t}}$ per year, or $\mathrm{y}_{\mathrm{t}}=$ $\mathrm{y}_{0}$, if $0<\mathrm{t}<\infty$.

The variables in the model are marked by the following symbols

$y_{o}=$ the value of the produce of the farm estate, mk

$\mathrm{y}_{1}=$ the value of the produce of the arable land area of the farm estate, mk

$y_{2}=$ the value of the produce of the forest land area of the farm estate, mk

$\mathrm{K}=$ the total area of the farm estate in hectares, $\mathrm{K}=\mathrm{P}+\mathrm{M}$

$\mathrm{P}=$ the arable land area of the farm estate in hectares

$\mathrm{M}=$ the forest land area of the farm estate in hectares

$\mathrm{p}_{1}=$ the unit price of the agricultural products, $\mathrm{mk}$

$\mathrm{p}_{2}=$ the unit price of the forest products, $\mathrm{mk}$

$\mathrm{q}_{1}=$ the sales price of the arable land, mk

$\mathrm{q}_{2}=$ the sales price of the forest land, $\mathrm{mk}$

$\mathrm{r}=$ the rate of interest in percents

$c_{1}=$ the costs of the arable land, mk

$\mathrm{c}_{2}=$ the costs of the forest, $\mathrm{mk}$

$\mathrm{S}=$ the sales price of the farm estate, $\mathrm{mk}$

$\mathrm{f}, \mathrm{g}, \mathrm{b}$, and $\mathrm{a}=$ constants

On assuming the production functions of the farm estate, on the part of the arable and forest land areas, as follows

(1) $y_{1}=f(P)$ and

(2) $y_{2}=g(M)$,

of which the former is obviously a non-linear and the latter a linear relation, the total produce of the farm estate is reached, providing that the functions are additive,

(3) $\mathrm{y}_{\mathrm{o}}=\mathrm{p}_{1} \mathrm{y}_{1}+\mathrm{p}_{2} \mathrm{y}_{2}=\mathrm{p}_{1} \mathrm{f}(\mathrm{P})+\mathrm{p}_{2} \mathrm{~g}(\mathrm{M})$.

The cost functions can be assumed to be

(4) $c_{1}=c_{1}(P)$ and

(5) $c_{2}=c_{2}(M)$, 
in which case the offer of the buyer, both for the agricultural land and the forest land areas rises probably, at the most, to the amount of the capitalized value, or

(6) $\mathrm{q}_{1} \leqq 1 / \mathrm{r}\left[\mathrm{p}_{1} \mathrm{f}(\mathrm{P})-\mathrm{c}_{1}(\mathrm{P})\right]$, and

(7) $\mathrm{q}_{2} \leqq 1 / \mathrm{r}\left[\left(\mathrm{p}_{2} \mathrm{~g}(\mathrm{M})-\mathrm{c}_{2}(\mathrm{M})\right]\right.$.

It is presumed that the seller will be satisfied at least in the capitalized value in question, so that in a situation of equilibrium, at the time point of the purchase, evidently only the equation sign will come into force. In accordance with what has been presented above, the sales price of the farm estate would be determined as follows:

(8) $\mathrm{S}=\mathrm{q}_{1}+\mathrm{q}_{2}=\mathrm{f}_{2}(\mathrm{P})+\mathrm{g}_{2}(\mathrm{M})$.

In the above examination the time factor has not been considered at all. This can be motivated by the fact that a farm estate is most often not acquired for a limited period of time and on the fact that in general the concept of depreciation is not used in connection with capital of this kind. Upon leaving the time factor without consideration, we arrive at the following hypothesis to be tested

(9) $\mathrm{S}=\mathrm{a}+\mathrm{b}_{1} \log (\mathrm{P})+\mathrm{b}_{2} \log (\mathrm{M})+\mathrm{u}$.

The regression coefficients to be estimated will contain, in accordance with the foregoing, such elements as the rate of interest, the productivity of the agricultural and forest land areas, and price and cost levels. The hypothesis is assumed to have the nature of an average so that special problems of aggregation in this connection will not be confronted.

\section{The results of the regression analysis}

With reference to the motivations presented above, it was endeavored to explain the sales price of farm estates by means of the arable and forest land areas. The values of both the dependent and independet variables are observations from the cross-section samples from the years 1961, 1962 and 1966. In order to base the analysis on a somewhat homogeneous data, and in order that the regional differences in the operation conditions of the farm estates would be taken into consideration, the explanatory models of the sales prices of farm estates have been estimated on the basis of the material covering the whole country as well as provincially. Table 1 illustrates the results of the regression analysis for the whole country.

In order to take into consideration the effect of the location of the estate, there are contained, in addition to $(\mathrm{P})$ and $(\mathrm{M})$, as the explanatory variables, ten dummy variables showing the provincial distribution of the sales of estates. These have been defined as follows:

\begin{tabular}{lcccccccccc} 
Province & $\mathrm{D}_{1}$ & $\mathrm{D}_{2}$ & $\mathrm{D}_{3}$ & $\mathrm{D}_{4}$ & $\mathrm{D}_{5}$ & $\mathrm{D}_{6}$ & $\mathrm{D}_{7}$ & $\mathrm{D}_{8}$ & $\mathrm{D}_{9}$ & $\mathrm{D}_{10}$ \\
\hline Turun ja Porin lääni & 0 & 0 & 0 & 0 & 0 & 0 & 0 & 0 & 0 & 0 \\
Hämeen lääni & 1 & 0 & 0 & 0 & 0 & 0 & 0 & 0 & 0 & 0 \\
Kymen lääni & 0 & 1 & 0 & 0 & 0 & 0 & 0 & 0 & 0 & 0 \\
Keski-Suomen lääni & 0 & 0 & 1 & 0 & 0 & 0 & 0 & 0 & 0 & 0 \\
Vaasan lääni & 0 & 0 & 0 & 1 & 0 & 0 & 0 & 0 & 0 & 0 \\
Kuopion lääni & 0 & 0 & 0 & 0 & 1 & 0 & 0 & 0 & 0 & 0 \\
Pohjois-Karjalan lääni & 0 & 0 & 0 & 0 & 0 & 1 & 0 & 0 & 0 & 0 \\
Mikkelin lääni & 0 & 0 & 0 & 0 & 0 & 0 & 1 & 0 & 0 & 0 \\
Uudenmaan lääni & 0 & 0 & 0 & 0 & 0 & 0 & 0 & 1 & 0 & 0 \\
Oulun lääni & 0 & 0 & 0 & 0 & 0 & 0 & 0 & 0 & 1 & 0 \\
Lapin lääni & 0 & 0 & 0 & 0 & 0 & 0 & 0 & 0 & 0 & 1 \\
\hline
\end{tabular}




\begin{tabular}{|c|c|c|c|c|}
\hline & $\approx$ & 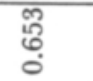 & $\begin{array}{l}\text { ली } \\
\text { గ̂ं }\end{array}$ & :్ర్రి \\
\hline & $a^{\circ}$ & 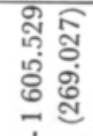 & 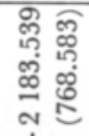 & 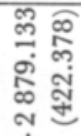 \\
\hline & ค̊ & 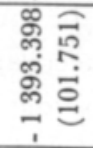 & 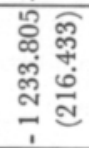 & 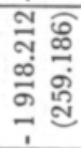 \\
\hline & $A^{\infty}$ & 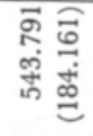 & 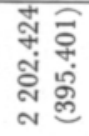 & 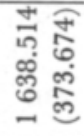 \\
\hline & ค' & 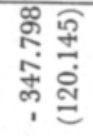 & 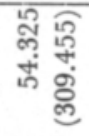 & 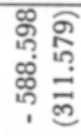 \\
\hline & $\stackrel{\circ}{\circ}$ & 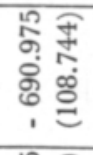 & 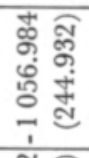 & 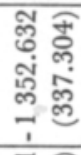 \\
\hline & $A^{\circ}$ & 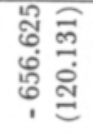 & 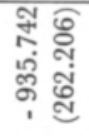 & 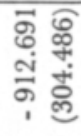 \\
\hline $\begin{array}{l}\text { క్ँ } \\
\text { ఫँ } \\
5\end{array}$ & $\vec{A}$ & 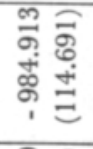 & 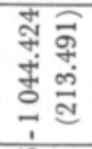 & 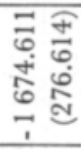 \\
\hline है & $a^{\infty}$ & 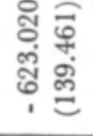 & 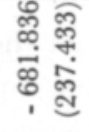 & 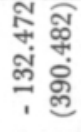 \\
\hline & $A^{n}$ & 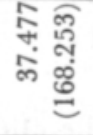 & 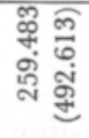 & 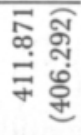 \\
\hline & $A^{-1}$ & 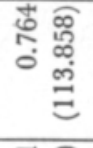 & 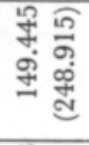 & 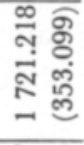 \\
\hline & $\begin{array}{l}\sum_{1} \\
\stackrel{\infty}{0}\end{array}$ & 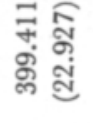 & 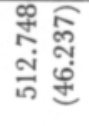 & 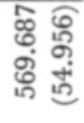 \\
\hline & $\begin{array}{l}01 \\
\stackrel{0}{0}\end{array}$ & 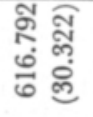 & 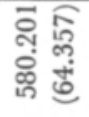 & 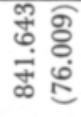 \\
\hline & $\pi^{\circ}$ & 흠 & $\begin{array}{l}\text { @े } \\
\text { ळ. } \\
\text { ळे }\end{array}$ & $\begin{array}{l}\text { लొ } \\
\text { స్టి } \\
\text { - }\end{array}$ \\
\hline & & ஜ & ఝै & ஜ \\
\hline
\end{tabular}


The sequence of the provinces has been fixed so that the province in which the highest fraction of the variance of the sales price is explained by the arable land area has been marked zero. The corresponding coefficient of determination is the second highest in the the second province, the purchases on the territory of which have been marked with 1 and with the symbol $D_{1}$ etc. Thus the province Turun ja Porin lääni forms the basis of the sales prices, and the signs and the absolute values of coefficient estimates of D-variables indicate in what direction and to what extent the location of the estate causes a variation in the sales price, as compared with the level existing in the province Turun ja Porin lääni.

The regression models explaining the sales prices of farm estates in the whole country are in conformity with the hypothesis in the sense that the signs of the regression coefficients of $\log (\mathrm{P})$ and $\log (\mathrm{M})$ are positive, as expected. However, these coefficient estimates are not elasticities in themselves; the elasticities are arrived at by dividing the regression coefficients by the sales price, or, using symbols, $\frac{b_{i}}{\mathrm{~s}}$. It can be established as a general observation that the absolute values of the coefficient estimates of area of arable land are higher than those of forest area, which indicates that the sales prices react more sensitively in accordance with the variation of the arable land area of the estate than the variation of the forest area. The decrease of the absolute value of the coefficient estimate of the agricultural land area from the year 1961 to the year 1962 is also to be observed, as well as the increase of the respective coefficient estimate for forest area during the same time period, which probably indicates the influence of the crop failure of 1962 and its effect on the sales prices of farm estates.

The estimates of the coefficients of the dummy variables indicate that the sales prices of farm estates do not vary significantly, notwithstanding a slight exception, when comparing the province Turun ja Porin lääni with the provinces Hämeen and Kymen lääni. On the other hand, sales prices are significantly lower in the provinces Keski-Suomen lääni, Vaasan lääni, Kuopion lääni and Pohjois-Karjalan lääni.

The level of the sales prices in the province Mikkelin läni does not deviate consistently from the level of the basic province, as again the price level in the province Uudenmaan lääni is significantly higher than that of the basic province. In the northernmost provinces, the provinces Oulun and Lapin lääni, the price level is naturally very much lower than that in the province Turun ja Porin läani. The coefficients of determination indicate that the areas explain only $29-43 \%$ of the variation in sales prices.

The regression equations were also estimated provincially. In table (2) there are, on the left side, the provincial estimates in accordance with the explanatory model (9) and on the right side there are the estimates of the double logarithmic functions, by the means of which examinations have been made with regard to the significance of the agricultural land and forest land area on the sales price for both arguments separately.

The equations on the left side of the table indicate that with the diminishing size of the sample, the dispersion increases, the statistical significance of the coefficient estimates decreases and the multicollinearity becomes very prominent in certain provinces, which can be seen from the high absolute values of the coefficient estimates and from the negative constant factors. As the size of the farms varies considerably in some provinces, as for example in the province Turun ja Porin lääni, the constant factors in these provinces are small and, correspondingly, the absolute values of the coefficient estimates 3 
Table 2. Regression Equations for the Sales Prices of Farm Estates and the Elasticities with regard to Arable land and Forest land Areas in 1961, 1962 and 1966.

\begin{tabular}{|c|c|c|c|c|c|c|c|c|}
\hline \multicolumn{9}{|c|}{ Provincially } \\
\hline & \multicolumn{3}{|c|}{$\begin{array}{l}\text { Regression coefficients } \\
\text { based on equation }(9)\end{array}$} & \multirow[b]{2}{*}{$\mathbf{R}$} & \multicolumn{3}{|c|}{ Elasticities and $\mathrm{R}^{2}$ 's } & \multirow[b]{2}{*}{$\mathrm{R}^{2}$} \\
\hline & $a_{0}$ & $\log P$ & $\log \mathrm{M}$ & & $\log \mathrm{P}$ & $\mathrm{R}^{2}$ & $\log \mathrm{M}$ & \\
\hline \multicolumn{9}{|l|}{ Uudenmaan lääni } \\
\hline 1961 & 604.180 & $\begin{array}{c}805.504 \\
(171.241)\end{array}$ & $\begin{array}{c}789.661 \\
(153.337)\end{array}$ & 0.735 & $\begin{array}{c}0.374 \\
(0.091)\end{array}$ & 0.236 & $\begin{array}{c}0.440 \\
(0.071)\end{array}$ & 0.408 \\
\hline 1962 & -701.625 & $\begin{array}{c}1286.221 \\
(1804.912)\end{array}$ & $\begin{array}{c}2435.623 \\
(1012.179)\end{array}$ & 0.676 & $\begin{array}{c}0.591 \\
(0.135)\end{array}$ & 0.389 & $\begin{array}{c}0.393 \\
(0.065)\end{array}$ & 0.547 \\
\hline 1966 & 2225.864 & $\begin{array}{c}90.109 \\
(420.338)\end{array}$ & $\begin{array}{c}1570.399 \\
(349.535)\end{array}$ & 0.600 & $\begin{array}{c}0.293 \\
(0.083)\end{array}$ & 0.195 & $\begin{array}{c}0.394 \\
(0.054)\end{array}$ & 0.510 \\
\hline \multicolumn{9}{|c|}{ Turun ja Porin lääni } \\
\hline 1961 & 130.370 & $\begin{array}{c}1123.997 \\
(80.800)\end{array}$ & $\begin{array}{l}429.474 \\
(61.389)\end{array}$ & 0.689 & $\begin{array}{c}0.643 \\
(0.031)\end{array}$ & 0.498 & $\begin{array}{c}0.387 \\
(0.027)\end{array}$ & 0.311 \\
\hline 1962 & 165.413 & $\begin{array}{c}1149.395 \\
(93.574)\end{array}$ & $\begin{array}{l}504.929 \\
(73.523)\end{array}$ & 0.703 & $\begin{array}{c}0.586 \\
(0.039)\end{array}$ & 0.448 & $\begin{array}{c}0.322 \\
(0.036)\end{array}$ & 0.219 \\
\hline 1966 & 231.325 & $\begin{array}{c}1927.154 \\
(196.731)\end{array}$ & $\begin{array}{c}310.863 \\
(142.753)\end{array}$ & 0.656 & $\begin{array}{c}0.652 \\
(0.057)\end{array}$ & 0.428 & $\begin{array}{c}0.192 \\
(0.053)\end{array}$ & 0.070 \\
\hline \multicolumn{9}{|l|}{ Hämeen lääni } \\
\hline 1961 & 368.850 & $\begin{array}{l}762.939 \\
(84.192)\end{array}$ & $\begin{array}{l}578.311 \\
(70.091)\end{array}$ & 0.762 & $\begin{array}{c}0.541 \\
(0.045)\end{array}$ & 0.438 & $\begin{array}{c}0.405 \\
(0.040)\end{array}$ & 0.355 \\
\hline 1962 & 460.625 & $\begin{array}{c}982.261 \\
(166.100)\end{array}$ & $\begin{array}{l}464.750 \\
(98.445)\end{array}$ & 0.714 & $\begin{array}{c}0.500 \\
(0.062)\end{array}$ & 0.407 & $\begin{array}{c}0.296 \\
(0.036)\end{array}$ & 0.407 \\
\hline 1966 & -1529.121 & $\begin{array}{l}3207.873 \\
(741.551)\end{array}$ & $\begin{array}{c}723.079 \\
(417.559)\end{array}$ & 0.651 & $\begin{array}{c}0.736 \\
(0.089)\end{array}$ & 0.535 & $\begin{array}{c}0.370 \\
(0.055)\end{array}$ & 0.428 \\
\hline \multicolumn{9}{|l|}{ Kymen lääni } \\
\hline 1961 & 614.196 & $\begin{array}{c}634.093 \\
(144.153)\end{array}$ & $\begin{array}{c}553.852 \\
(114.271)\end{array}$ & 0.727 & $\begin{array}{c}0.496 \\
(0.079)\end{array}$ & 0.370 & $\begin{array}{c}0.402 \\
(0.062)\end{array}$ & 0.385 \\
\hline 1962 & -835.883 & $\begin{array}{l}2112.614 \\
(678.332)\end{array}$ & $\begin{array}{l}-13.702 \\
(433.060)\end{array}$ & 0.659 & $\begin{array}{c}0.622 \\
(0.158)\end{array}$ & 0.464 & $\begin{array}{c}0.235 \\
(0.126)\end{array}$ & 0.163 \\
\hline 1966 & -736.648 & $\begin{array}{l}1715.274 \\
(484.294)\end{array}$ & $\begin{array}{l}1088.290 \\
(394.325)\end{array}$ & 0.666 & $\begin{array}{c}0.490 \\
(0.095)\end{array}$ & 0.393 & $\begin{array}{c}0.415 \\
(0.076)\end{array}$ & 0.424 \\
\hline \multicolumn{9}{|l|}{ Mikkelin lääni } \\
\hline 1961 & 384.033 & $\begin{array}{l}466.262 \\
(93.571)\end{array}$ & $\begin{array}{l}534.790 \\
(83.683)\end{array}$ & 0.630 & $\begin{array}{c}0.371 \\
(0.050)\end{array}$ & 0.253 & $\begin{array}{c}0.382 \\
(0.042)\end{array}$ & 0.335 \\
\hline 1962 & 472.416 & $\begin{array}{r}-592.655 \\
(788.308)\end{array}$ & $\begin{array}{l}1376.565 \\
(627.037)\end{array}$ & 0.290 & $\begin{array}{l}0.282 \\
(0.129)\end{array}$ & 0.080 & $\begin{array}{c}0.428 \\
(0.090)\end{array}$ & 0.290 \\
\hline 1966 & -374.987 & $\begin{array}{c}579.905 \\
(261.648)\end{array}$ & $\begin{array}{l}1214.329 \\
(200.724)\end{array}$ & 0.620 & $\begin{array}{c}0.321 \\
(0.073)\end{array}$ & 0.184 & $\begin{array}{c}0.389 \\
(0.045)\end{array}$ & 0.458 \\
\hline \multicolumn{9}{|c|}{ Pohjois-Karjalan lääni } \\
\hline 1961 & 359.689 & $\begin{array}{c}397.139 \\
(68.700)\end{array}$ & $\begin{array}{l}410.274 \\
(50.034)\end{array}$ & 0.621 & $\begin{array}{c}0.448 \\
(0.050)\end{array}$ & 0.267 & $\begin{array}{r}0.368 \\
(0.035)\end{array}$ & 0.339 \\
\hline 1962 & 572.490 & $\begin{array}{l}154.146 \\
(81.611)\end{array}$ & $\begin{array}{c}350.393 \\
(56.522)\end{array}$ & 0.575 & $\begin{array}{c}0.186 \\
(0.070)\end{array}$ & 0.066 & $\begin{array}{c}0.307 \\
(0.040)\end{array}$ & 0.374 \\
\hline 1966 & 140.508 & $\begin{array}{c}625.122 \\
(253.837)\end{array}$ & $\begin{array}{c}623.341 \\
(130.540)\end{array}$ & 0.607 & $\begin{array}{c}0.476 \\
(0.129)\end{array}$ & 0.168 & $\begin{array}{c}0.385 \\
(0.056) \\
\end{array}$ & 0.414 \\
\hline
\end{tabular}


$\begin{array}{llllllll}\mathrm{a}_{\mathrm{o}} & \log \mathrm{P} & \log \mathrm{M} & \mathrm{R} & \log \mathrm{P} & \mathrm{R}^{2} & \log \mathrm{M} & \mathrm{R}^{2}\end{array}$

\begin{tabular}{rlllllllll}
\hline Kuopion läåni & & & & & & & & \\
1961 & 734.115 & 516.200 & 183.920 & 0.498 & 0.434 & 0.278 & 0.233 & 0.132 \\
& & $(99.878)$ & $(77.985)$ & & $(0.055)$ & & $(0.047)$ & \\
1962 & 245.552 & 485.948 & 444.475 & 0.662 & 0.416 & 0.205 & 0.403 & 0.455 \\
& & $(125.082)$ & $(81.344)$ & & $(0.089)$ & & $(0.048)$ & \\
1966 & \multirow{2}{*}{559.886} & 685.545 & 593.272 & 0.621 & 0.327 & 0.213 & 0.315 & 0.230 \\
& & $(142.603)$ & $(132.056)$ & & $(0.065)$ & & $(0.059)$ &
\end{tabular}

\begin{tabular}{cccccccccc}
\hline $\begin{array}{c}\text { Keski-Suomen lääni } \\
1961\end{array}$ & 99.637 & 485.492 & 541.630 & 0.702 & 0.498 & 0.296 & 0.429 & 0.397 \\
& & $(118.393)$ & $(88.211)$ & & $(0.073)$ & & $(0.051)$ & \\
1962 & \multirow{2}{*}{446.700} & 473.876 & 456.328 & 0.592 & 0.411 & 0.219 & 0.359 & 0.372 \\
& & $(143.420)$ & $(96.181)$ & & $(0.073)$ & & $(0.044)$ & \\
1966 & - & 46.277 & 1266.102 & 979.970 & 0.723 & 0.624 & 0.447 & 0.519 & 0.559 \\
& & $(329.610)$ & $(245.241)$ & & $(0.102)$ & & $(0.068)$ &
\end{tabular}

\begin{tabular}{ccccccccc}
\hline Vaasan lääni & & & & & & & & \\
1961 & 278.533 & 440.010 & 276.392 & 0.558 & 0.496 & 0.232 & 0.323 & 0.227 \\
& & $(86.301)$ & $(56.773)$ & & $(0.067)$ & & $(0.044)$ & \\
1962 & \multirow{2}{*}{629.814} & 312.778 & 191.738 & 0.520 & 0.269 & 0.152 & 0.180 & 0.114 \\
& & $(64.348)$ & $(49.672)$ & & $(0.052)$ & & $(0.041)$ & \\
\multirow{2}{*}{1966} & \multirow{2}{*}{359.523} & 581.165 & 333.171 & 0.664 & 0.417 & 0.246 & 0.247 & 0.231 \\
& & $(98.241)$ & $(59.974)$ & & $(0.065)$ & & $(0.040)$ & \\
\hline
\end{tabular}

Oulun lääni

$\begin{array}{ccccccccc}1961 & 455.160 & 184.381 & 241.269 & 0.497 & 0.275 & 0.110 & 0.264 & 0.225 \\ & & (50.296) & (33.651) & & (0.047) & & (0.030) & \\ 1962 & 525.521 & 69.780 & 413.612 & 0.598 & 0.234 & 0.100 & 0.309 & 0.362 \\ & & (73.426) & (51.075) & & (0.057) & & (0.034) & \\ 1966 & 455.801 & 273.938 & 407.453 & 0.531 & 0.293 & 0.143 & 0.288 & 0.244 \\ & & (93.000) & (69.781) & & (0.053) & & (0.038) & \end{array}$

are high. On the other hand, in some provinces, in the actual small-farm territories, the areas of the farms vary only slightly, for which reason the constant factors are high and the absolute values of the coefficient estimates are relatively small. These factors render difficult provincial comparison. In addition, it is evident that it has not been possible, in the province Uudenmaan lääni, to limit the statistical data to consist only of farm estates used for agriculture and forestry purposes despite screening, as the arable land area coefficient estimates for 1962 and 1966 have an absolute value much smaller than that of forest land area. It seems probable that the sample includes some sales of estates purchased for vacation and other non-agricultural purposes, in which cases the total area of the farm estate (the indicator of which is probably the forest area) and the location have been decisive arguments in explaining the price.

Provincial comparison within the framework of the estimates of the explanatory model is not fully motivated as can be observed from the above and for this reason the right side of table 2, in which the regression coefficients represent the agricultural and 


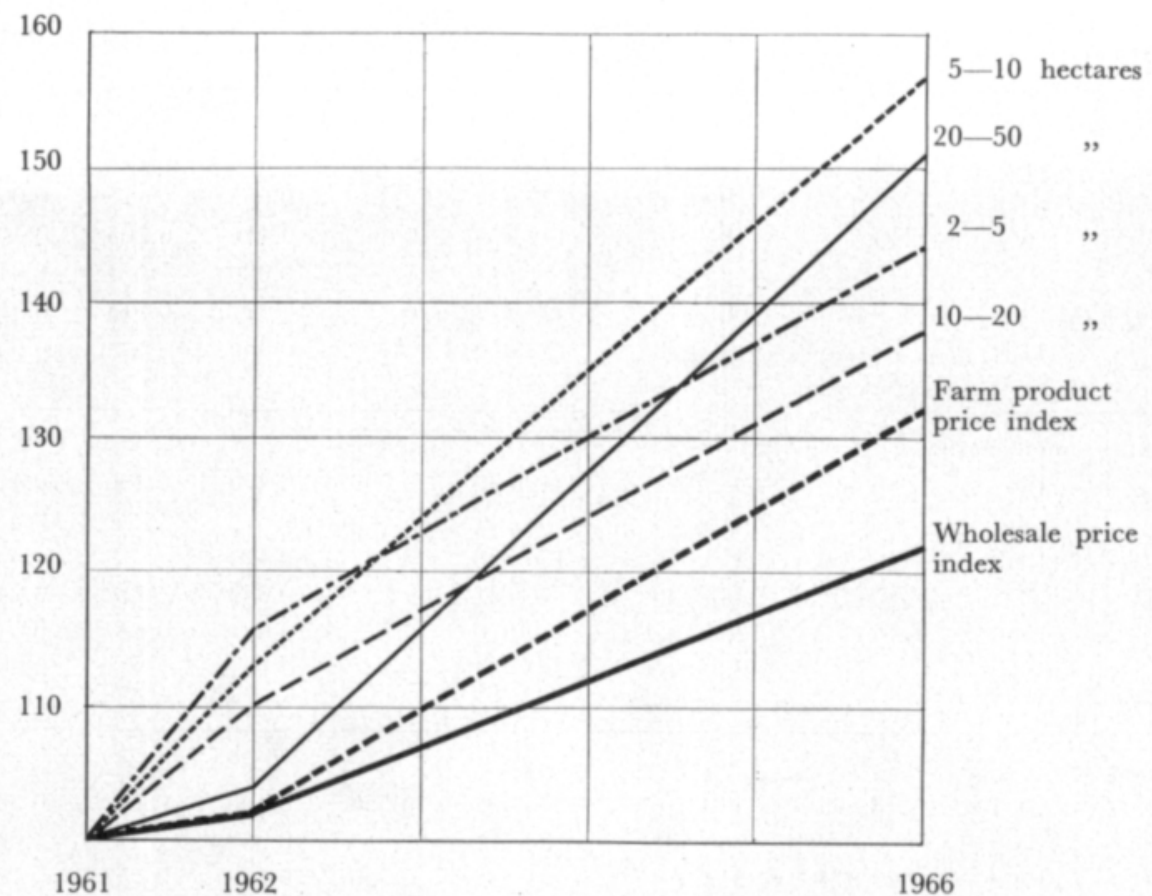

Figure 1. The sales prices of farm estates according to the total area in 1961, 1962 and 1966.

forest land area elasticities directly, separately calculated, and the $\mathrm{R}^{2}$ 's, gives more information on regional differences.

The results obtained from the province Uudenmaan lääni are, however, similar to those given by the explanatory model referred to above. Instead, in the provinces Turun ja Porin lääni, Hämeen lääni and Vaasan lääni, the arable land area is consistently more important than the forest area in explaining the variance of sales prices, deducing from the value of the $R^{2}$. On the same basis it is established that the forest land area is a stronger argument than the area of arable land in explaining the sales prices in the provinces Mikkelin lääni, Pohjois-Karjalan lääni, Keski-Suomen lääni and Oulun lääni, while the results of the other provinces are indefinite.

The region of the provinces Turun ja Porin lääni, Hämeen lääni and Kymen lääni is such in which the agricultural area elasticities are greatest and thus the sales prices react more sensitively to the variations of the areas of arable land. The opposite has been the case in the province Keski-Suomen lääni, where an increase of $10 \%$ in the forest area was followed by an increase of $3.6-5.2 \%$ in the sales price.

It can be proved that the results from the province Lapin lääni are not reliable on account of the limited data and the irregular environments in the province. For this reason these results will not be referred.

\section{$S u m m a r y$}

As general conclusions of the performed regression analysis it can be established that the increase of both agricultural and forest land areas increases the sales price less than proportionally (elasticity $<1$ ) and that the area of arable land, the forest land and 
the dummy variables explain, in 1961, about $43 \%$, in $196229 \%$ and in 1966 about $39 \%$ of the changes of the sales prices of farm estates in the whole country.

From the provincial models it can be observed that the variance of sales prices explained is highest in the field cultivation territory, i.e. the provinces Turun ja Porin lääni, Hämeen lääni and Kymen lääni, in which it varies from $42-58 \%$. On the other hand, in the "forest region" of Finland, i.e. in the provinces Keski-Suomen lääni and PohjoisKarjalan lääni, the variance explained was also high, being $33-52 \%$. The lowest $\mathrm{R}^{2}$ s were found in the provinces Mikkelin lääni, Vaasan lääni and Oulun lääni. Thus many other factors, such as the quality of the land, the location of the estate with regard to population centers, the buildings, roads and environmental factors, which could not be included in this research, are evidently important arguments of the sales price. It would thus be necessary to expand the research in suchwise that the explanatory efficiency of the mentioned variables would be tested, which would, again, mean a considerable decrease of the size of the sample, because it would be necessary to obtain the data by means of expensive field research and interviews (BRIGHAM 1965).

As it is difficult to find out the movements of the price level of farm estates by means of the regression analysis, here will be given the sales prices of estates in the whole country by averages, according to size categories, which averages are compared with the development of the indicators of the general price level (the basic year being the same in all series, $1961=100)$.

\begin{tabular}{|c|c|c|c|c|}
\hline & 1961 & 1962 & 1966 \\
\hline \multicolumn{2}{|c|}{ The wholesale price index: the general index of home market goods $(1935=100)$} & 100 & 102 & 122 \\
\hline \multirow{2}{*}{\multicolumn{2}{|c|}{ The producer price index for agricultural products $(1937-39=100)$}} & 100 & 102 & 132 \\
\hline & & 100 & 104 & 131 \\
\hline \multicolumn{5}{|c|}{ The sales prices of farm estates in the whole country according to the total area } \\
\hline area $2-5 \quad 1$ & hectares & 100 & 116 & 144 \\
\hline,$\quad 5-10$ & , & 100 & 113 & 157 \\
\hline $10-20$ & , & 100 & 110 & 138 \\
\hline $20-50$ & , & 100 & 104 & 151 \\
\hline,$\quad 50-$ & $"$ & 100 & 127 & 148 \\
\hline \multicolumn{5}{|c|}{$\begin{array}{l}\text { The sales prices of farm estates in the whole country according to the area of } \\
\text { arable land }\end{array}$} \\
\hline \multicolumn{2}{|c|}{ area $2-5$ hectares } & 100 & 110 & 136 \\
\hline,$\quad 5-10$ & , & 100 & 106 & 149 \\
\hline $10-20$ & , & 100 & 101 & 156 \\
\hline, $20-50$ & " & 100 & 135 & 160 \\
\hline \multicolumn{5}{|c|}{$\begin{array}{l}\text { The sales prices of farm estates in the whole country according to the forest } \\
\text { land area }\end{array}$} \\
\hline area $2-5 \quad 1$ & hectares & 100 & 122 & 154 \\
\hline $5-10$ & , & 100 & 109 & 156 \\
\hline $10-20$ & , & 100 & 100 & 140 \\
\hline $20-50$ & , & 100 & 113 & 163 \\
\hline $50-$ & " & 100 & 125 & 131 \\
\hline
\end{tabular}

As can be observed from the above table and figure 1 the sales prices of farm estates have risen considerably more in the years 1961-1966 than the general price level as measured by the Wholesale Price Index or the Cost of Living Index. Relatively the greatest price increase has taken place in farm estates with 5-10 hectares, and thereafter in sequence farm estates with 20-50 hectares, more than 50 hectares, $2-5$ hectares and $10-20$ hectares. It is also to be observed that the sales prices of all farm estates have risen more than the Producer Price Index for Agricultural Products. 
Acknowledgment. The writer wants to express his thanks to professor Paavo Kaarlehto and Mr. Lauri Kettunen, Dr. Pol. Sc., who have read the first version of the manuscript, for the many suggestions for improvement which have been duly observed. $\mathrm{Mr}$. Kari Lammi, M. A., has assisted the writer in dealing with the statistical data and in calculations, for which the writer thanks him.

\section{REFERENCES}

Brigham, E. F. 1965. The Determinants of Residential Land Values, Land Economics, Nov.

LEPonIEMI, A. ja LAMMI, K. 1961, 1962 ja 1966. Maatalouskiinteistöjen kauppahinnat Suomessa vuosina 1961, 1962 ja 1966. Kyösti Haatajan rahaston tutkimustoimisto, Sarja D 1968:1, Monistettuja tutkimuksia. (The Sales Prices of Farm Estates in Finland in the Years 1961, 1962 and 1966, The Research Bureau of the Kyösti Haataja Foundation, Series D 1968:1, duplicated research works)

Nõv, J. 1955. Lantbrukets fastighetsvärdering med särskild hänsyn till den doktrinhistoriska bakgrunden; Meddelanden från ekonomiska institutionerna, Kungl. Lantbrukshögskolan, Uppsala, 15 s.

\section{S E L O S T U S}

\section{MAATALOUSKIINTEISTÖJEN KAUPPAHINTOJEN RIIPPUVAISUUS PELTO- JA METSÄ- PINTA-ALASTA SUOMESSA vv. 1961, 1962 ja 1966}

\section{Arvi Leponiemi}

\section{Kyōsti Haatajan Rahaston tutkimustoimisto, Helsinki}

Yleisinä johtopäätöksinä suoritetusta regressioanalyysistå todetaan, että sekä pelto- että metsäpinta-alan suureneminen lisäävät alisuhteisesti maatalouskiinteistön kauppahintaa (jousto $<1$ ) ja, että maatalouskiinteistöjen kauppahintojen vaihtelusta koko maassa v. 1961 pelto- ja metsäpinta-ala sekä läänejä osoittavat dummy-muuttujat selittävät n. $43 \%$, v. $196229 \%$ ja v. 1966 n. $39 \%$.

Lääneittäisistä malleista todetaan, että mallien selitysaste on korkein peltoviljelysalueilla, Turun ja Porin, Hämeen ja Kymen lääneissä, joissa se vaihtelee $42 \%$ :sta $58 \%$ :iin. Toisaalta metsä-Suomessa, eli Keski-Suomen ja Pohjois-Karjalan lääneissä estimoitujen suhteiden selitysaste oli vain hieman alempi, 33-52 \%. Alhaisimmillaan selitysaste oli Mikkelin, Vaasan ja Oulun lääneissä. Näin ollen monet muut tekijät, kuten maan laatu, kiinteistöjen sijainti asutuskeskuksiin nähden, rakennukset, tiet, ja ympäristötekijät, joita tässä tutkimuksessa ei voitu ottaa huomioon, ovat ilmeisen tärkeitä kauppahinnan argumentteja. Tutkimusta olisi siis laajennettava niin, että mainittujen muuttujien selitystehokkuutta kokeiltaisiin, mikä toisaalta merkitsisi näytteen huomattavaa supistumista, sillä aineisto olisi hankittava kalliiden kenttä- ja haastattelututkimusten tietä.

Tämän tutkimuksen perustana käytetty tilastoaineisto (Leponiemi ja Lammi. Maatalouskiinteistöjen kauppahinnat Suomessa vuosina 1961, 1962 ja 1966) on saatavissa kirjoittajalta monisteena. 